\title{
Compromised Hemodynamic Response in Amyloid Precursor Protein Transgenic Mice
}

\author{
Thomas Mueggler, ${ }^{1}$ Christine Sturchler-Pierrat, ${ }^{2}$ Diana Baumann, ${ }^{1}$ Martin Rausch, ${ }^{1}$ Matthias Staufenbiel, ${ }^{2}$ \\ and Markus Rudin ${ }^{1}$
}

${ }^{1}$ Central Technologies and 2Nervous System Research, Novartis Pharma, AG, CH-4002 Basel, Switzerland

\begin{abstract}
APP23 transgenic mice overexpressing amyloid precursor protein $\left(\mathrm{APP}_{751}\right)$ reproduce neuropathological changes associated with Alzheimer's disease such as high levels of amyloid plaques, cerebral amyloid angiopathy, and associated vascular pathologies. Functional magnetic resonance imaging (fMRI) was applied to characterize brain functionality in these mice through global pharmacological stimulation. The cerebral hemodynamic response to infusion of the GABA $A_{A}$ antagonist bicuculline was significantly reduced in aged APP23 mice compared with age-
\end{abstract}

matched wild-type littermates. This is in part attributable to a compromised cerebrovascular reactivity, as revealed by the reduced responsiveness to vasodilatory stimulation by acetazolamide. The study shows that $\mathrm{fMRI}$ is a sensitive tool to phenotype genetically engineered animals modeling neuropathologies.

Key words: acetazolamide; amyloid precursor protein (APP); $\beta$-amyloid; transgenic mice; $G A B A_{A}$ antagonist; functional magnetic resonance imaging (fMRI); $P \mathrm{Pt}_{\mathrm{CO}_{2}}$
Transgenic mice overexpressing human amyloid precursor protein (APP23) contain an $\mathrm{APP}_{751}$ cDNA with the Swedish double mutation at position 670/671 under the control of the neuronspecific Thy-1 promoter. They express human $\mathrm{APP}_{751}$ in sevenfold excess compared with endogenous murine APP. The APP23 mouse model reproduces neuropathological changes associated with Alzheimer's disease (AD) such as high levels of amyloid plaques with a core of $\beta$-amyloid $(\mathrm{A} \beta)$. These deposits start to appear with 6 months of age predominantly in the neocortex and hippocampus and increase in number and size until 24 months of age, at which time they occupy substantial portions of the cortex, hippocampus, and thalamus (Sturchler-Pierrat et al., 1997). In addition to amyloid plaques, the mouse model develops cerebrovascular accumulation of $\mathrm{A} \beta$, although the APP transgene is only expressed in neurons (Calhoun et al., 1999). The cerebral amyloid angiopathy (CAA) and associated pathologies such as microhemorrhages in APP23 mice (Winkler et al., 2001) exhibit similarities to those observed in aged individuals and AD patients (Probst et al., 1991; Staufenbiel et al., 1997).

Multiple magnetic resonance imaging (MRI) approaches to assess AD-related changes in pathomorphology and pathophysiology in patients with prodromal AD and established AD have been reported previously (Tanabe et al., 1997; Bobinski et al., 1999; Fox et al., 1999; Brunetti et al., 2000; De Toledo-Morrell et al., 2000; Hirono et al., 2000; Laakso et al., 2000; Rombouts et al., 2000). Studies of cerebral blood volume (CBV) and perfusion suggest increasing prevalence of compromised brain perfusion in the temporoparietal cortex as the disease progresses (Sandson et al., 1996; Maas et al., 1997; Harris et al., 1998; Alsop et al., 2000). More recently, functional MRI (fMRI) using cognitive tasks revealed significant differences between the activation patterns in patients with probable AD and healthy volunteers (Johnson et al.,

Received Jan. 28, 2002; revised May 15, 2002; accepted May 15, 2002.

Correspondence should be addressed to Dr. Markus Rudin, CT/Analytical and Imaging Sciences Unit, WSJ-386.2.02, Novartis Pharma AG, CH-4002 Basel, Switzerland. E-mail: markus-1.rudin@pharma.novartis.com.

Copyright (ㄷ) 2002 Society for Neuroscience $\quad 0270-6474 / 02 / 227218-07 \$ 15.00 / 0$
2000; Thulborn et al., 2000). Such tests are potentially predictive for a subsequent memory decline (Bookheimer et al., 2000). Progressive impairment of cognitive functions has also been reported for APP23 transgenic mice (Sommer et al., 2000), suggesting a link to the pathomorphological and pathophysiological changes already described.

Winkler et al. (2001) reported that CAA in these mice leads to a loss of vascular smooth muscle cells, to aneurysm-like vasodilatation, and, in rare cases, to vessel obliteration and vasculities consistently throughout the neocortex, hippocampus, and thalamus, the severity of which increases with age. It is conceivable that the severe vasculopathies observed in APP23 mice compromise the ability of the cerebral vessels to regulate cerebral blood flow $(\mathrm{CBF})$. The ability of cerebral vessels to react to the demand of a global and/or local adequate perfusion increase, respectively (i.e., cerebral vasoreactivity) (Grossmann and Koeberle, 2000) can be assessed by inhalation of $\mathrm{CO}_{2}$ or intravenous injection of acetazolamide (Gambhir et al., 1997).

The purpose of this study was to examine whether compromised cerebral function and/or cerebral perfusion capacity can be assessed in APP23 mice using a noninvasive fMRI method. Recently, dynamic mapping of changes in $\mathrm{CBV}\left(\mathrm{CBV}_{\text {rel }}\right)$ associated with neuronal activation during pharmacological stimulation has been reported for mice (Mueggler et al., 2001). Infusion of the $\mathrm{GABA}_{\mathrm{A}}$ antagonist bicuculline led to dose-dependent $\mathrm{CBV}_{\mathrm{rel}}$ increases in various brain structures (e.g., cortex and caudate putamen). In the current study, we have compared the $\mathrm{CBV}_{\text {rel }}$ response to bicuculline stimulation in APP23 mice aged 7.5, 15, and 24 months and age-matched littermates. The cerebral perfusion capacity was measured using an acetazolamide challenge in 6- and 25-month-old APP23 mice.

\section{MATERIALS AND METHODS}

Animals. The generation of APP23 mice containing the murine Thy- 1 promoter driving neuron-specific expression of human mutated $\mathrm{APP}_{751}$ has been described in detail previously (Sturchler-Pierrat et al., 1997). fMRI studies with bicuculline stimulation were performed in agematched APP23 and control littermates at $23.8 \pm 1$ of age $(23.9 \pm 1$ for 
controls), $14.8 \pm 0.5$ of age $(15 \pm 0.5)$, and $7.7 \pm 0.1$ months of age $(7.6 \pm$ $0.1)$. The APP23 mice used in the acetazolamide experiments were $24.8 \pm 1$ months of age $(24.9 \pm 1$ for control mice $)$ and $5.7 \pm 0.8$ months of age $(5.8 \pm 0.7)$.

Animal preparation. All animal experiments were performed in strict adherence to the Swiss Law for Animal Protection. Animals were anesthetized using an initial dose of $3 \%$ isoflurane (Abbott, Cham, Switzerland) in air/ $\mathrm{O}_{2}(2: 1)$, intubated with a tube made from polyethylene (PE; inner diameter, $0.4 \mathrm{~mm}$; outer diameter, $0.8 \mathrm{~mm}$ ), and artificially ventilated using a ventilator for small animals (KTR 3; Alfos Electronics, Biel-Benken, Switzerland) with electronically controlled valves. Applying a pressure output of $2-2.5 \mathrm{kPa}$ and a respiration rate at $100-120$ breaths/min, an inspiration/expiration ratio of 0.20 was required to maintain blood $\mathrm{CO}_{2}$ values within the physiological range. For fMRI measurements, the animals were positioned in a cradle made from Plexiglas and kept anesthetized with $1.4 \%$ isoflurane in air/ $\mathrm{O}_{2}(2: 1)$. For intravenous infusion of the contrast agent, bicuculline and acetazolamide, the tail vein was cannulated with a 30 gauge needle (Microlance 3, $0.3 \times 13$; Becton Dickinson, Bioscience, Allschwil, Switzerland) that was connected with PE tubing to an infusion pump. The animals were then paralyzed with $10 \mathrm{mg} / \mathrm{kg}$ intravenous gallamine triethiode (Aldrich, Milwaukee, WI $)$ in saline $(3 \mathrm{mg} / \mathrm{ml})$. Body temperature was maintained at $36.5 \pm 1{ }^{\circ} \mathrm{C}$ using warm air, regulated by a rectal temperature probe (DM 852; Ellab, Copenhagen, Denmark). Blood $\mathrm{CO}_{2}$ levels were monitored transcutaneously $\left(\mathrm{Ptc}_{\mathrm{CO}_{2}}\right)$ during the experiment using a pediatric monitoring device (TCM3; Radiometer, Copenhagen, Denmark). An electrode was fixed on the shaved and cleaned skin with a self-adhesive fixation ring. The inner part of the fixation ring was filled with contact liquid (Radiometer Copenhagen). The electrode was heated up to a working temperature of $44^{\circ} \mathrm{C}$ and calibrated before each study using a standard calibration gas containing $5 \% \mathrm{CO}_{2}$ and $20.9 \% \mathrm{O}_{2}$ with the balance as nitrogen. $\mathrm{Ptc}_{\mathrm{CO}_{2}}$ was automatically corrected to correspond to a body temperature of $37^{\circ} \mathrm{C}$ (Siggaard-Andersen, 1965; Severinghaus, $1965)$ and by subtracting a metabolic correction factor of $4 \mathrm{mmHg}$ (Severinghaus, 1982).

MRI protocol. Experiments were performed on a Biospec 47/15 and a Pharmascan 70/16 system (Bruker, Karlsruhe, Germany). The radiofrequency probe was a birdcage resonator of $28 \mathrm{~mm}$ inner diameter. The imaging protocol for the assessment of $\mathrm{CBV}_{\text {rel }}$ changes consisted of a multislice rapid acquisition with relaxation enhancement (RARE) sequence (Hennig et al., 1986) with the following parameters: repetition time, $1135 \mathrm{msec}$; echo time (TE), $6.7 \mathrm{msec}$; RARE factor, 32; effective TE, $80 \mathrm{msec}$; field of view, $2.56 \times 2.56 \mathrm{~cm}^{2}$; matrix dimension, $128 \times 128$; slice thickness, $1 \mathrm{~mm}$; number of slices, 2 ; interslice distance, $2 \mathrm{~mm}$; and spectral width, $50 \mathrm{kHz}$. Recording four averages, the image acquisition time amounted to $21 \mathrm{sec}$. For positioning of the transverse imaging slices 0.38 and $-0.94 \mathrm{~mm}$ relative to the bregma, a sagittal RARE image matrix dimension of $128 \times 128$ with eight averages and a slice thickness of $1 \mathrm{~mm}$ in the sagittal plane has been measured.

fMRI protocol for bicuculline experiments. A series of 128 images was acquired for the assessment of $\mathrm{CBV}_{\text {rel }}$ changes. The measurement comprised three parts: First a baseline image was acquired, which was used for calibration of $\mathrm{CBV}_{\text {rel }}$ changes. Thereafter scanning was interrupted and Endorem (11.2 mg/ml; Guerbet, Roissy, France) at a dose of 70 $\mathrm{mg} / \mathrm{kg}$ (50 mg/ $\mathrm{kg}$ for 6 -month-old mice) was administered via the tail vein. Scanning was continued after a 15 min delay, which was introduced to achieve steady-state signal intensity. After the acquisition of 15 postcontrast baseline images, (+)-bicuculline (Sigma-Aldrich, Buchs, Switzerland) was infused at a dose of $0.5 \mathrm{mg} \cdot \mathrm{kg}^{-1} \cdot \mathrm{min}^{-1}$ for six images $(2$ $\mathrm{min})$, followed by a slower infusion of $1 / 10 \mathrm{th}$ of the original rate for the subsequent 30 images, corresponding to total doses of $1.5 \mathrm{mg} / \mathrm{kg}$. Because of frequently observed seizure-like strong $\mathrm{CBV}_{\text {rel }}$ decreases in both groups at 6 months of age using $1.5 \mathrm{mg} / \mathrm{kg}$, the total dose was reduced for this age: Infusion of $0.33 \mathrm{mg} \cdot \mathrm{kg}^{-1} \cdot \mathrm{min}^{-1}$ for the first 2 min followed $1 / 10$ th of this dose, leading to a total dose of $1 \mathrm{mg} / \mathrm{kg}$. The infusion protocol was adopted from previous studies (Reese et al., 2000; Mueggler et al., 2001).

fMRI protocol for acetazolamide experiments. MRI parameters were identical to the bicuculline experiments. At $20 \mathrm{~min}$ after infusion of Endorem at a dose of $50 \mathrm{mg} / \mathrm{kg}$, a series of 90 images was performed. After 15 baseline images, acetazolamide (Diamox; Wyeth Pharmaceuticals, Zug, Switzerland) at dose of $30 \mathrm{mg} / \mathrm{kg}(2 \mathrm{ml} / \mathrm{kg})$ was injected intravenously as a bolus.

Image analysis. Ten minutes after infusion, the plasma concentration of Endorem has reached a steady state. Hence, the changes in the relative amount of tracer in cerebral voxels, which can be calculated from $-\ln \left\{S(t) / \bar{S}_{0}\right\}$, where $S(t)$ denotes the signal intensity at time $t$ and $\bar{S}_{0}$ indicates the average intensity before bicuculline infusion, directly reflect changes in $\mathrm{CBV}$. Changes of $\mathrm{CBV}_{\text {rel }}$ in percentage of prestimulation values $\left(\triangle \mathrm{CBV}_{\%}\right)$ were therefore computed from the spin echo data on a pixel-by-pixel basis according to

$$
\Delta \mathrm{CBV}_{\%}(t)=\frac{\Delta \mathrm{CBV}_{\text {rel }}}{\mathrm{CBV}_{\text {rel }}} \times 100=\frac{\ln \left\{S(t) / \bar{S}_{0}\right\}}{\ln \left\{\bar{S}_{0} / \bar{S}_{\text {pre }}\right\}} \times 100,
$$

with $\bar{S}_{\text {pre }}$ being the signal intensity before injection of contrast agent. Two regions of interest (ROIs) were defined for cortical gray matter and one representing the thalamic nuclei (see Fig. 2). The dimensions of the cortical and thalamic ROIs were 3.0 and $5.0 \mathrm{~mm}^{3}$, respectively. The readouts of the cortical ROIs were averaged to yield one $\Delta \mathrm{CBV}_{\%}(t)$ value per region and time point. All data analysis was performed using imaging analysis software developed in-house (Biomap version 3.1). Data in text and figures are expressed as mean \pm SEM, unless stated otherwise. The two-group comparison was analyzed by the two-tailed $t$ test for independent samples. Multiple comparisons were evaluated by the ANOVA. $p$ values of $<0.05$ were considered to be statistically significant.

\section{RESULTS}

\section{Reduced cerebral hemodynamic response to stimulation with $\mathrm{GABA}_{\mathrm{A}}$ antagonist in aged APP23 mice}

Systemic infusion of bicuculline $(1.5 \mathrm{mg} / \mathrm{kg})$ led to a transient increase in local $\mathrm{CBV}_{\text {rel }}$ as illustrated for two transverse brain sections of 15-month-old mice (Fig. 1a,b). In control littermates, cortical CBV (in percentage of basal values) increased by $\Delta \mathrm{CBV}_{\%}=50 \pm 7 \%$ throughout the duration of bicuculline infusion. The corresponding $\mathrm{CBV}_{\text {rel }}$ response in APP23 mice was reduced in amplitude and delayed compared with control littermates. The thalamic $\mathrm{CBV}_{\text {rel }}$ increases after bicuculline infusion were smaller than in the cortex, displayed a delayed onset, and did not differ between APP23 and wild-type mice of 15 months age.

Quantitative image analysis yielded $\triangle \mathrm{CBV}_{\%}$ versus time curves for the cortical ROI (Fig. 1c) in response to bicuculline administration, as shown for 7.5- and 24-month-old mice (Fig. 2a,b). In the younger animals, infusion of bicuculline at a dose of $1 \mathrm{mg} / \mathrm{kg}$ led to $\Delta \mathrm{CBV}_{\%}$ increases of $35 \pm 4 \%$ in control animals $(n=6)$ and $39 \pm 5 \%$ in APP23 mice $(n=6)$. In the cortical ROIs of 24-month-old mice, $\Delta \mathrm{CBV}_{\%}$ increased by $48 \pm 7 \%$ in nontransgenic animals $(n=6)$ and only $21 \pm 4 \%$ in APP23 mice $(n=6)$ after infusion of bicuculline at a dose of $1.5 \mathrm{mg} / \mathrm{kg} . \triangle \mathrm{CBV}_{\%}$ of both aged APP23 and aged-matched control animals peaked at $\sim 3.5-4 \mathrm{~min}$ after the onset of the infusion. In the thalamus, $\Delta \mathrm{CBV}_{\%}$ increases of $26 \pm 5 \%$ and $7 \pm 2 \%$ have been measured in 24-month-old control and transgenic mice, respectively. Again, no significant differences between controls and APP23 mice have been observed in 7.5-month-old animals $(18.5 \pm 4 \%$ and $21.5 \pm 4 \%$ ).

The temporal profiles of transcutaneously measured $\mathrm{CO}_{2}$ partial pressure $\left(\mathrm{Ptc}_{\mathrm{CO}_{2}}\right)$ obtained using on-line monitoring in 7.5and 24-month-old mice displayed no significant effect of bicuculline inf usion (Fig. 2e). Similarly, there was no difference in $\mathrm{Ptc}_{\mathrm{CO}_{2}}$ values measured for control and APP23 mice at both ages. Mean values of $\mathrm{Ptc}_{\mathrm{CO}_{2}}$ at the start of the infusion period were $37 \pm 1$ $\mathrm{mmHg}$ for control littermates and $36.5 \pm 2$ for the APP23 mice at 7.5 months and $36 \pm 2$ and $35 \pm 1 \mathrm{mmHg}$, respectively, for the 24-month-old animals.

For the average $\Delta \mathrm{CBV}_{\%}$ increase (Fig. $3 a, b$ ) during bicuculline inf usion (range, 0-12 min), significant differences between transgenic and control mice have been observed for both cortical and thalamic ROIs at 24 months of age $(p=0.016$ and $p=0.002$; 
Figure 1. Temporal evolution of $\mathrm{CBV}_{\text {rel }}$ during infusion of the $\mathrm{GABA}_{\mathrm{A}}$ antagonist bicuculline $(1.5 \mathrm{mg} / \mathrm{kg})$. For $\triangle \mathrm{CBV}_{\%}$ maps, 10 images were averaged for each interval $(210$ $\mathrm{sec})$. Infusion of bicuculline: $t=0-720 \mathrm{sec}$. Multislice experiments were conducted using two transverse brain sections $0.38 \mathrm{~mm}(a)$ and $-0.94 \mathrm{~mm}(b)$ relative to the bregma of a 15 -month-old control and an age-matched APP23 mouse. In control littermates, a prominent increase in cortical $\mathrm{CBV}_{\text {rel }}$ has been observed throughout the bicuculline infusion. In contrast, the cortical response to bicuculline stimulation was clearly reduced in amplitude and delayed in an APP23 mouse. The more caudal section also reveals a $\mathrm{CBV}_{\text {rel }}$ increase in the thalamus. Thalamic $\triangle \mathrm{CBV}_{\%}$ values were smaller than those in the cortex and displayed a delayed onset. Similar amplitudes of $\triangle \mathrm{CBV}_{\%}$ during infusion of bicuculline have been observed in control and APP23 mice. ROIs indicated by white outlines in the somatosensory cortex and thalamus of the mouse brain in transverse slices $0.38 \mathrm{~mm}$ anterior $(c)$ and $0.94 \mathrm{~mm}$ posterior $(d)$ relative to the bregma, respectively, were used for quantitative analysis of the $\mathrm{CBV}_{\text {rel }}$ changes and corresponding anatomical images taken from the brain atlas (Rosen, 2000). S1, Pri-
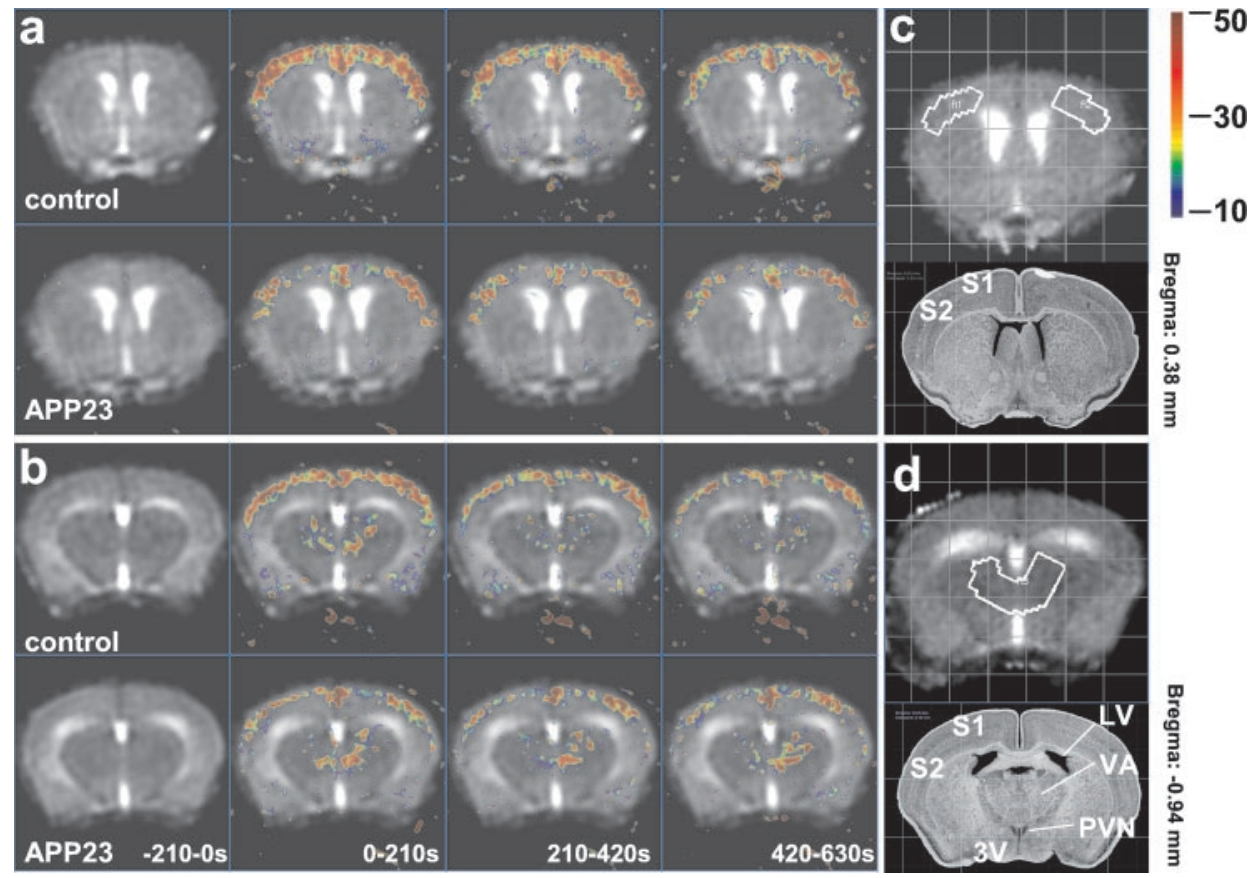

mary somatosensory cortex; $S 2$, secondary somatosensory cortex; $L V$, lateral ventricle; $3 V$, third ventricle; $P V N$, paraventricular thalamic nucleus; $V A$, ventral anterior thalamic nucleus.

ANOVA) but not at 15 months of age $(p=0.11$ and $p=0.89$ ANOVA; $n=5)$ and 7.5 months of age with the lower dose of 1 $\mathrm{mg} / \mathrm{kg}(p=0.3$ and $0.89 ; t$ test $)$.

Analysis of data of 15- and 24-month-old animals showed a significant effect of age for the thalamic response of APP23 transgenics ( $p=0.013$; ANOVA).

For maximum cortical $\triangle \mathrm{CBV}_{\%}$ values (data not shown), statistical analysis revealed significant differences between APP23 transgenic and age-matched control mice at both 24 and 15 months of age $(p=0.003$ and $p=0.035$; ANOVA) but not at 7.5 months of age ( $t$ test). In the thalamus, significant differences of maximum $\triangle \mathrm{CBV}_{\%}$ values between the two genotypes have been observed only at 24 months of age ( $p=0.015$; ANOVA).

\section{Compromised cerebrovascular reactivity in aged APP23 mice}

To obtain independent information on the cerebrovascular reactivity, an analogous study was performed assessing the effects of acetazolamide on $\mathrm{CBV}_{\text {rel }}$ (Fig. 2b,d). In both the cerebral cortex and the thalamus, relative $\mathrm{CBV}$ increased immediately after injection. At 6 months of age, cortical blood volume changes reached maximum values of $45 \pm 6 \%$ in controls $(n=6)$ and $42 \pm$ $5 \%$ in APP23 mice $(n=6)$. In aged control littermates at 25 months of age $(n=4)$, values of the order of $\Delta \mathrm{CBV}_{\%}=28 \pm 2 \%$ have been measured after 4-6 min, followed by a slower increase until the end of the experiment reaching maximum values of $\Delta \mathrm{CBV}_{\%}=35 \pm 5 \%$ after $24 \mathrm{~min}$. The corresponding response in 25-month-old APP23 mice $(n=6)$ showed a significantly smaller increase in $\Delta \mathrm{CBV}_{\%}=18 \pm 4 \%$ and a distinct slower onset during the first $6 \mathrm{~min}$, leveling off at $\Delta \mathrm{CBV}_{\%}=25 \pm 3 \%$ at the end of the experiment.

The $\mathrm{Ptc}_{\mathrm{CO}_{2}}$ monitoring during administration of acetazolamide revealed a significant increase in $\mathrm{Ptc}_{\mathrm{CO}_{2}}$ with an onset $\sim 1$ min after injection (Fig. 2f). At both ages, neither the $\mathrm{Ptc}_{\mathrm{CO}_{2}}$ value at injection of acetazolamide $(36 \pm 4$ and $36 \pm 2 \mathrm{mmHg}$ at 6 months of age, $39.5 \pm 4$ and $40 \pm 2 \mathrm{mmHg}$ for control and
APP23 mice at 25 months of age, respectively) nor the maximum increases after $15 \mathrm{~min}\left(\Delta \mathrm{Ptc}_{\mathrm{CO}_{2}}=22 \pm 5\right.$ and $22 \pm 2$ at 6 months of age, $\Delta \mathrm{Ptc}_{\mathrm{CO}_{2}}=28 \pm 5$ and $29.6 \pm 3$ for control littermates and APP23 mice at 25 months of age, respectively) differed significantly between the two groups.

Analysis of the average $\Delta \mathrm{CBV}_{\%}$ increase (Fig. 3a,b) after acetazolamide injection (range, $0-24 \mathrm{~min}$ ) revealed significant differences between control and APP23 mice for both cortical and thalamic ROIs at the age of 25 months only ( $p=0.032$ and $p=$ 0.038; ANOVA). A significant effect of age was found for the cortical regions of 25- and 6-months-old APP23 mice ( $p=0.004$; ANOVA).

\section{Hemispheric imbalance in cortical fMRI signals in APP23 mice}

Whereas the $\mathrm{CBV}_{\text {rel }}$ changes measured in nontransgenic littermates were always identical within error limits for both hemispheres, three of the APP23 transgenic mice at 24 months of age showed a significant asymmetry of the hemispheric $\mathrm{CBV}_{\text {rel }}$ responses to bicuculline stimulation. $\triangle \mathrm{CBV}_{\%}$ differences between the right and left somatosensory cortex on the order of $10-15 \%$ have been measured.

\section{fMRI response did not correlate with body weight and hence absolute dose of stimulant}

There was a difference in body weight between control animals and APP23 mice that reached statistical significance at 15 and 25 months of age ( $p<0.001$ and $p=0.013$; ANOVA). Analysis of signal intensities before and after infusion of $50 \mathrm{mg} / \mathrm{kg}$ contrast agent in the 25-month-old mice revealed no significant difference between the two groups ( $t$ test), suggesting a linear relationship between body weight and blood volume over the examined range of 27-41 gm. However, body weight is a potentially confounding factor, because the total amount of bicuculline administered was significantly lower in the transgenic groups. Nevertheless, we have found no correlation between the $\Delta \mathrm{CBV}_{\%}$ increases after infu- 

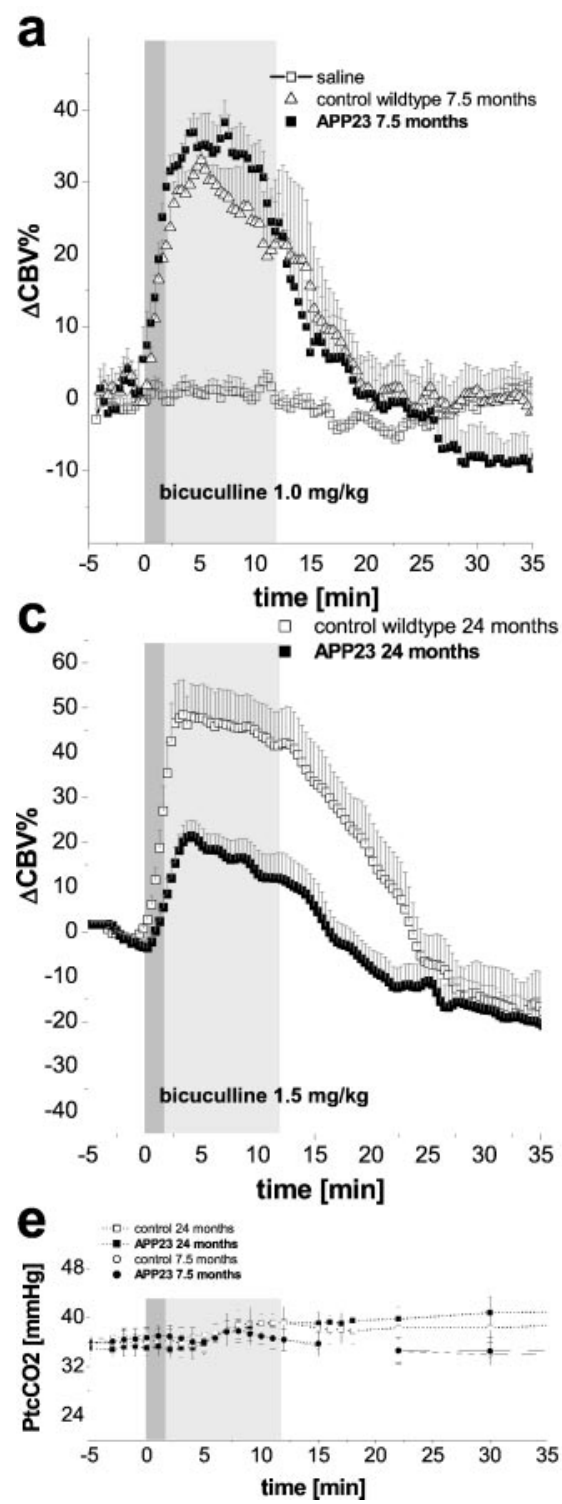
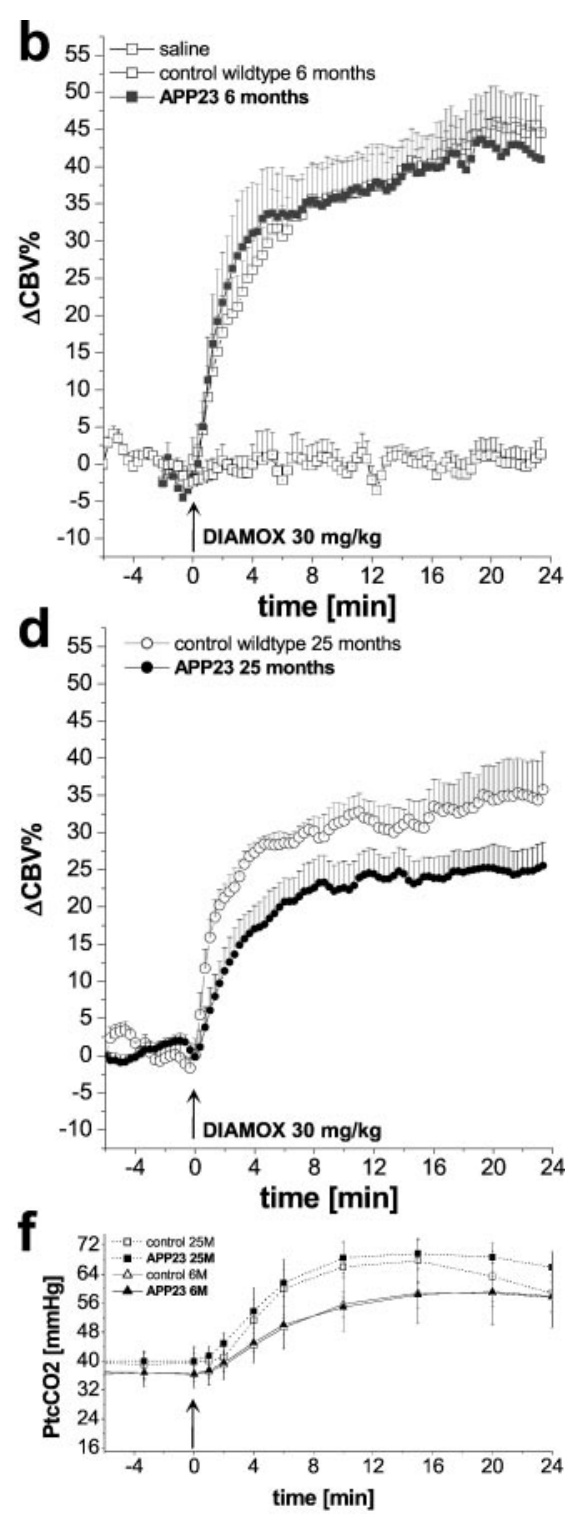

Figure 2. $\triangle \mathrm{CBV}_{\%}$ changes in the cortical ROIs defined in Figure $1 c$ after administration of bicuculline at a dose of $1 \mathrm{mg} / \mathrm{kg}(a)$ and acetazolamide $(D I A M O X)$ at a dose of $30 \mathrm{mg} / \mathrm{kg}(b)$ for 7.5 - and 6-month-old APP23 mice and age-matched controls, respectively. Control and APP23 mice show similar $\Delta \mathrm{CBV}_{\%}$ changes. In aged mice (24 months of age), the cortical response to the inf usion of bicuculline at a dose of $1.5 \mathrm{mg} / \mathrm{kg}(c)$ is significantly lower in transgenic animals compared with their littermates. The temporal profile after injection of acetazolamide (arrows) for 25-month-old APP23 mice and age-matched controls again revealed significantly lower $\triangle \mathrm{CBV}_{\%}$ changes in transgenic animals compared with their littermates $(d)$. Ptc $\mathrm{CO}_{2}$ values obtained during online monitoring are shown at the bottom $(e, f)$. Gray bars indicate the different infusion rates of the first 2 and subsequent $10 \mathrm{~min}$. Data represent mean \pm SEM. sion of bicuculline at a dose of $1.5 \mathrm{mg} / \mathrm{kg}$ and the body weight within both the control and the transgenic groups; linear regression yielded $r=0.027$ ( $p=0.94 ; n=11$; range, 22-30 gm) for the transgenic group and $r=-0.025(p=0.94 ; n=11$; range, $27-38$ $\mathrm{gm})$ for control animals.

\section{DISCUSSION}

\section{Compromised response to bicuculline in aged APP23 transgenic mice}

fMRI revealed a significantly compromised cerebral hemodynamic response to stimulation with the $\mathrm{GABA}_{\mathrm{A}}$ antagonist bicuculline in 24-month-old APP23 mice compared with their wild-type littermates in both cortical and thalamic ROIs. In 15-month-old mice, only the maximal $\mathrm{CBV}_{\text {rel }}$ response to bicuculline in the cortex was significantly reduced. No difference in $\mathrm{CBV}_{\text {rel }}$ response between APP23 mice and controls was observed at 7.5 months of age. At this age, the higher dose of bicuculline used in 15- and 24-month-old mice led to strong blood volume decreases in cortical structures after a short initial $\mathrm{CBV}_{\text {rel }}$ enhancement, as described in a previous study in Hanlbm/Naval Medical Research Institute mice (Mueggler et al., 2001). This CBV response ob- served in APP23 mice but also in one control animal at a larger concentration of the $\mathrm{GABA}_{\mathrm{A}}$ antagonist can be caused by seizure-like activity leading to an uncoupling of blood flow and metabolism and seems to be age dependent. Therefore, the total dose for the youngest animals was reduced to $1 \mathrm{mg} / \mathrm{kg}$. The $\mathrm{CBV}_{\text {rel }}$ response at this lower dose is consistent with a previously published dose-response curve (Mueggler et al., 2001). Hemodynamic parameters ( $\mathrm{Ptc}_{\mathrm{CO}_{2}} / \mathrm{Pa}_{\mathrm{CO}_{2}}$; body temperature) that might cause unspecific changes of $\mathrm{CBV}$ did not vary significantly during and after bicuculline infusion; in fact, the $\mathrm{Ptc}_{\mathrm{CO}_{2}}$ values for the APP23 mice and their age-matched littermates were identical within error limits. This rules out the possibility that the observed $\mathrm{CBV}_{\text {rel }}$ changes induced by bicuculline are caused by hypercapnia or hypocapnia.

The amplitude of the CBV response after bicuculline stimulation has been shown to correlate with the density of $\mathrm{GABA}_{\mathrm{A}}$ receptors in the rat brain (Reese et al., 2000). Hence, the smaller hemodynamic response in the APP23 mice compared with their littermates could reflect a difference in the $\mathrm{GABA}_{\mathrm{A}}$ binding sites in the corresponding brain regions. In view of the disinhibitory action of $\mathrm{GABA}_{\mathrm{A}}$, antagonist impairment of additional neuronal 


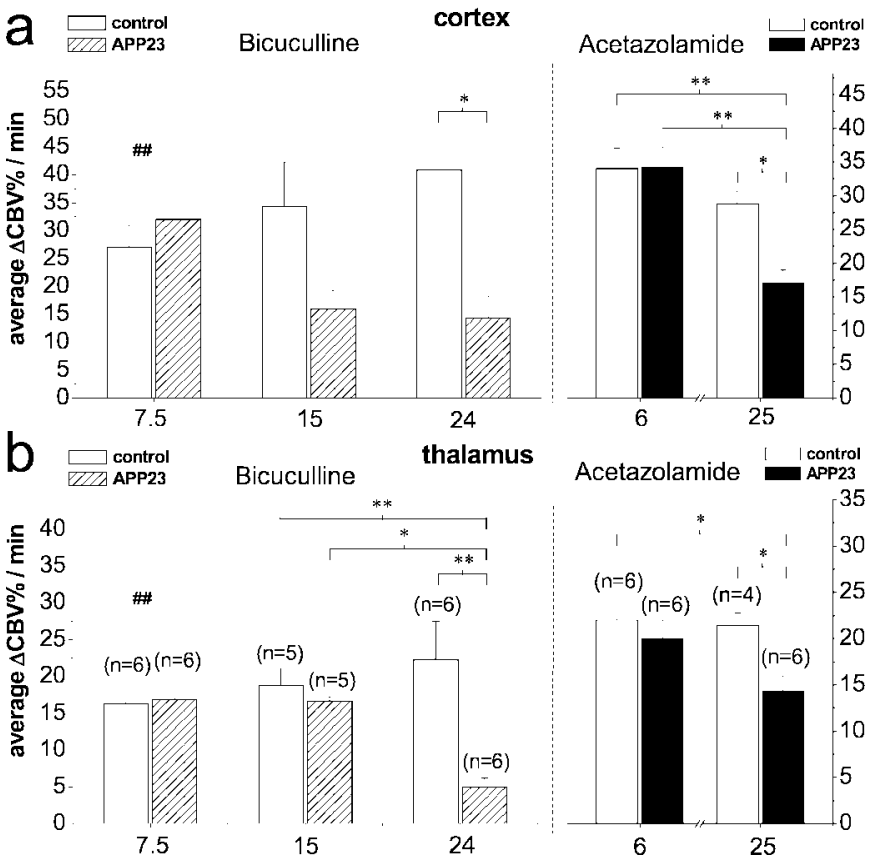

Figure 3. Averaged $\triangle \mathrm{CBV}_{\%}$ during the total infusion period for cortical $(a)$ and thalamic $(b)$ ROIs revealed a significantly reduced response in 24-month-old APP23 mice compared with their littermates for bicuculline at a dose of $1.5 \mathrm{mg} / \mathrm{kg}$ and acetazolamide at a dose of $30 \mathrm{mg} / \mathrm{kg}\left({ }^{*} p<0.05\right.$ and ${ }^{*} p<0.01$; ANOVA) at 24 and 25 months of age, respectively. Infusion of bicuculline at a dose of $1 \mathrm{mg} / \mathrm{kg}$ in 7.5 -month-old mice revealed no significant difference between control and APP23 mice $(t$ test). Values are given as mean \pm SEM. ${ }^{\# \#}$ Note the lower dose of 1 $\mathrm{mg} / \mathrm{kg}$ at 7.5 months of age.

transmitter systems might explain the compromised functional response in the transgenic animals: Distortions of the cholinergic fibers in regions containing plaques and an overall reduction in the number of fibers has been reported in APP23 mice (SturchlerPierrat et al., 1997), suggesting that, similar to humans (Tago et al., 1987; Geula and Mesulam, 1989), the cholinergic system is strongly affected. Other structural-morphological changes comprise dystrophic (swollen) neocortical neurites that are abundant in the vicinity of the $A \beta$ immunoreactive plaques that occupy up to $26 \%$ of the total volume of neocortex in transgenic mice. Deposits were regularly found in the hippocampus and become detectable at late stages in the thalamus. It is reasonable to assume that such structural changes might impair neuronal connectivity (Staufenbiel et al., 1997; Sturchler-Pierrat and Staufenbiel, 2000). The fMRI study in young animals at 7.5 months of age might indicate that the compromised functionality is caused by elevated $\mathrm{A} \beta$ levels rather than by APP overexpression itself.

\section{Compromised $\mathbf{C B V}_{\text {rel }}$ response to acetazolamide}

Considering the vascular pathologies described for the APP23 model (Calhoun et al., 1999; Winkler et al., 2001), the reduced $\mathrm{CBV}_{\text {rel }}$ response to bicuculline stimulation might be associated with impaired vascular reactivity. In fact, intravenous administration of acetazolamide caused a significantly smaller $\mathrm{CBV}_{\text {rel }}$ increase in aged APP23 mice ( 25 months) in both the cerebral cortex and the thalamus. The $\mathrm{CBV}_{\text {rel }}$ responses to acetazolamide of APP23 mice and their littermates at 6 months of age were identical within error limits in both brain regions examined.

Acetazolamide, a potent inhibitor of the carbonic anhydrase, acidifies cerebral extracellular fluids by elevating the brain extra- cellular fluid $\mathrm{P}_{\mathrm{CO}_{2}}$, which is thought to be the stimuli for the increase in CBF (and CBV) (Vorstrup et al., 1984). However, the exact mechanism by which acetazolamide increases CBF has not been clarified. Because of the slow penetration of the blood-brain barrier (Roth et al., 1959; Maren, 1967), direct inhibition of parenchymal carbonic anhydrase cannot explain the fast CBF increase measured immediately after infusion (Kohshi et al., 1994). Another side of action of carbonic anhydrase inhibition is considered to be the erythrocytes: Acetazolamide has been shown to easily penetrate red blood cells, causing a decrease in the $\mathrm{CO}_{2}$-carrying capacity of blood and increasing the $\mathrm{P}_{\mathrm{CO}_{2}}$ gradient between brain tissue and blood (Maren, 1967) within minutes. Alternatively, acetazolamide-induced inhibition of carbonic anhydrase located on the brain capillary endothelium (Ridderstrale and Hanson, 1985; Ghandour et al., 1992) might cause $\mathrm{CO}_{2}$ retention in the tissue (Maren, 1977), which might lead to the pronounced cerebrovascular response. In our study, transcutaneous on-line monitoring of $\mathrm{P}_{\mathrm{CO}_{2}}$ revealed $\mathrm{Ptc}_{\mathrm{CO}_{2}}$ increases of the order of $22 \mathrm{mmHg}$ at 6 months of age in both groups and 28 and $30 \mathrm{mmHg}$ at 25 months of age in control and APP23 mice, respectively. Under normal conditions, $\mathrm{Ptc}_{\mathrm{CO}_{2}}$ values have been shown to reflect $\mathrm{Pa}_{\mathrm{CO}_{2}}$ values in mice (Mueggler et al., 2001). The profound increase in $\mathrm{Ptc}_{\mathrm{CO}_{2}}$ observed in mice after acetazolamide treatment may reflect the increasing $\mathrm{P}_{\mathrm{CO}_{2}}$ gradient between the tissue and the arterial or mixed venous blood, respectively. A direct link between the elevated brain extracellular fluid $\mathrm{P}_{\mathrm{CO}_{2}}$ /tissue acidification and the increase in $\mathrm{CBF}$ has not been established. The mechanism seems to be different from the one induced by hypercapnia, as suggested by the capacity of nitric oxide inhibitors to block their action (Csete et al., 2001).

\section{Cerebral vascular dysfunction and CAA}

$\mathrm{A} \beta$ staining revealed significant CAA consistently throughout the neocortex, hippocampus, and thalamus in aged 19- and 27-monthold APP23 mice. Earlier phases of CAA involve focal discontinuity of the smooth muscle cell layer, which progresses to a dramatic loss of smooth muscle cells in the tunica media of amyloid-laden vessels, with only patchy staining for smooth muscle cell actin remaining (Calhoun et al., 1999; Winkler et al., 2001). The significantly reduced hemodynamic response to the acetazolamide and to some extent probably also to the bicuculline challenge in 25- and 24-month-old APP23 mice, respectively, may reflect these severe CAA-related vasculopathies (Probst et al., 1991; Staufenbiel et al., 1997) impairing the ability of the cerebral arteriolar and/or capillary compartment to effectively regulate $\mathrm{CBF}$. Hence, the increased metabolic rate resulting from neuronal activation might not translate into a change in hemodynamic parameters that is detectable by fMRI. Consistent with this hypothesis, a profound structural and functional disruption of vascular smooth muscle cells in pial vessels in 14-month-old mice overexpressing APP ( $\mathrm{Tg} 2576)$ has been reported (Christie et al., 2001), and these mice display a similarly compromised ability to respond appropriately to endothelium-dependent and endothelium-independent vasodilators. This can be attributed to increased wall stiffness caused by amyloid deposition. However, in another transgenic APP model $(\mathrm{Tg} 1130 \mathrm{H}$ on a Friend virus B background) that does not express amyloid deposits and displays a normal hemodynamic response to endothelial-independent stimuli, cerebral endothelial dysf unction has been measured after endothelial-dependent induced vasodilation (Iadecola et al., 1999). This impairment has been related to an $\mathrm{A} \beta$ peptide (from APP overexpression) compromising endothelial-dependent vaso- 
dilatation. Moreover, it has been shown that the reduced CBF response to vasoactive agents and functional activation produced by somatosensory stimulation in 2-month-old mice devoid of parenchymal and vascular $\mathrm{A} \beta$ deposits correlates with cerebral $\mathrm{A} \beta(1-40)$ levels. Despite a reduced CBF, the animal showed normal neural activation; also the activation-induced cerebral glucose uptake was not altered in these transgenic mice. This supports the hypothesis that $\mathrm{A} \beta(1-40)$ has direct vascular effects (Niwa et al., 2000a,b).

Parenchymal $A \beta$ levels have been reported to increase already in 6-month-old APP23 mice (Sommer et al., 2000), whereas CAA has not been observed at an age of 8 months (Calhoun et al., 1999). The normal fMRI response of the 6- and 7.5-month-old APP23 mice may thus be attributed to the absence of CAA at this age. Alternatively, the still low parenchymal plaque load at this age might be insufficient to reduce neuronal and associated vascular reactivity to the applied stimulus. In both humans and mice, development of CAA and development of amyloid plaques appear to be independent processes, both naturally depending on A $\beta$ level and age as risk factors (Greenberg et al., 1995; Calhoun et al., 1999). The loss of smooth muscle cells as an early and severe consequence of CAA caused by toxic extracellular $\mathrm{A} \beta$ has been described previously. As in APP23 mice, the transgenic A $\beta$ is of neuronal origin (Calhoun et al., 1999), and smooth muscle cell degeneration is caused by drainage of soluble $\mathrm{A} \beta$ along perivascular spaces or through corticothalamic axonal transport before draining along the vessels. Hence in APP23 mice CAA has a slower onset than the parenchymal $\mathrm{A} \beta$ plaque formation. Later in CAA pathogenesis, disruption of the tight link between the perivascular astrocytic ending and the vessel wall (glial-vascular interface) occurs, followed by infiltration of vascular amyloid into the neuropil, causing aneurysmal dilatations. CAA in adult APP23 mice leads to local perivascular neurodegeneration, including neuron loss and dystrophic terminals (Calhoun et al., 1999; Phinney et al., 1999). This suggests that the chronic toxic effect of CAA on the parenchyma is an important factor leading to cognitive impairment in APP23 mice (Winkler et al., 2001). The significant differences in the fMRI response observed in our study probably reflect CAA-related vasculopathies. Hence the described fMRI method in this mouse model can be helpful to assess the functional consequences of vascular deposits and reevaluate the role of CAA in AD-related cognitive impairment.

In conclusion, we have shown using fMRI that the response to GABAergic stimulation is significantly compromised in aged APP23 transgenic mice compared with their wild-type littermates. This is in part attributable to an impaired vascular reactivity as reflected by a reduced response to the carbonic anhydrase inhibitor acetazolamide in 25-month-old APP23 transgenic mice. This reduced ability to respond to a vasodilatory challenge reflects the severe vasculopathies described for APP-overexpressing mouse lines. The extent to which the reduced response to $\mathrm{GABA}_{\mathrm{A}}$ inhibition is caused by impaired neural excitability or by the lack of cerebrovascular reactivity remains to be determined. In addition to these specific conclusions, our study reveals that fMRI is an attractive tool for phenotyping of genetically engineered mice developed as model of human neuropathologies.

\section{REFERENCES}

Alsop DC, Detre JA, Grossman M (2000) Assessment of cerebral blood flow in Alzheimer's disease by spin-labeled magnetic resonance imaging. Ann Neurol 47:93-100.

Bobinski M, De Leon MJ, Convit A, De Santi S, Wegiel J, Tarshish CY,
Saint LL, Wisniewski HM (1999) MRI of entorhinal cortex in mild Alzheimer's disease. Lancet 353:38-40.

Bookheimer SY, Stroiwas MH, Cohen MS, Saunders AM, Pericak-Vance MA, Mazziotta JC, Small GW (2000) Patterns of brain activation in people at risk for Alzheimer's disease. N Engl J Med 343:450-456.

Brunetti A, Postiglione A, Tedeschi E, Ciarmiello A, Quarantelli M, Covelli EM, Milan G, Larobina M, Soricelli A, Sodano A, Alfano B (2000) Measurement of global brain atrophy in Alzheimer's disease with unsupervised segmentation of spin-echo MRI studies. J Magn Reson Imaging 11:260-266.

Calhoun ME, Burgermeister P, Phinney AL, Stalder M, Tolnay M, Wiederhold KH, Abramowski D, Sturchler-Pierrat C, Sommer B, Staufenbiel M, Jucker M (1999) Neuronal overexpression of mutant amyloid precursor protein results in prominent deposition of cerebrovascular amyloid. Proc Natl Acad Sci USA 96:14088-14093.

Christie R, Yamada M, Moskowitz M, Hyman B (2001) Structural and functional disruption of vascular smooth muscle cells in a transgenic mouse model of amyloid angiopathy. Am J Pathol 158:1065-1071.

Csete K, Barzo P, Bodosi M, Papp JG (2001) Influence of nitrovasodilators and cyclooxygenase inhibitors on cerebral vasoreactivity in conscious rabbits. Eur J Pharmacol 412:301-309.

De Toledo-Morrell L, Goncharova I, Dickerson B, Wilson RS, Bennett DA (2000) From healthy aging to early Alzheimer's disease: in vivo detection of entorhinal cortex atrophy. Ann NY Acad Sci 911:240-253.

Fox NC, Warrington EK, Rossor MN (1999) Serial magnetic resonance imaging of cerebral atrophy in preclinical Alzheimer's disease. Lancet 353:2125.

Gambhir S, Inao S, Tadokoro M, Nishino M, Ito K, Ishigaki T, Kuchiwaki H, Yoshida J (1997) Comparison of vasodilatory effect of carbon dioxide inhalation and intravenous acetazolamide on brain vasculature using positron emission tomography. Neurol Res 19:139-144.

Geula C, Mesulam M (1989) Special properties of cholinesterases in the cerebral cortex of Alzheimer's disease. Brain Res 498:185-189.

Ghandour MS, Langley OK, Zhu XL, Waheed A, Sly WS (1992) Carbonic anhydrase IV on brain capillary endothelial cells: a marker associated with the blood-brain barrier. Proc Natl Acad Sci USA 89:6823-6827.

Greenberg SM, Rebeck GW, Vonsattel JP, Gomez-Isla T, Hyman BT (1995) Apolipoprotein E $\epsilon 4$ and cerebral hemorrhage associated with amyloid angiopathy. Ann Neurol 38:254-259.

Grossmann WM, Koeberle B (2000) The dose-response relationship of acetazolamide on the cerebral blood flow in normal subjects. Cerebrovasc Dis 10:65-69.

Harris GJ, Lewis RF, Satlin A, English CD, Scott TM, Yurgelun-Todd DA, Renshaw PF (1998) Dynamic susceptibility contrast MR imaging of regional cerebral blood volume in Alzheimer disease: a promising alternative to nuclear medicine. AJNR Am J Neuroradiol 19:1727-1732.

Hennig J, Nauerth A, Friedburg H (1986) RARE imaging: a fast imaging method for clinical MR. Magn Reson Med 3:823-833.

Hirono N, Kitagaki H, Kazui H, Hashimoto M, Mori E (2000) Impact of white matter changes on clinical manifestation of Alzheimer's disease: a quantitative study. Stroke 31:2182-2188.

Iadecola C, Zhang F, Niwa K, Eckman C, Turner SK, Fischer E, Younkin S, Borchelt DR, Hsiao KK, Carlson GA (1999) SOD1 rescues cerebral endothelial dysfunction in mice overexpressing amyloid precursor protein. Nat Neurosci 2:157-161.

Johnson SC, Saykin AJ, Baxter LC, Flashman LA, Santulli RB, McAllister TW, Mamourian AC (2000) The relationship between fMRI activation and cerebral atrophy: comparison of normal aging and Alzheimer disease. NeuroImage 11:179-187.

Kohshi K, Konda N, Kinoshita Y, Tsuru E, Yokota A (1994) In situ arterial and brain tissue $\mathrm{PCO} 2$ responses to acetazolamide in cats. J Appl Physiol 76:2199-2203.

Laakso MP, Frisoni GB, Kononen M, Mikkonen M, Beltramello A Geroldi C, Bianchetti A, Trabucchi M, Soininen H, Aronen HJ (2000) Hippocampus and entorhinal cortex in frontotemporal dementia and Alzheimer's disease: a morphometric MRI study. Biol Psychiatry 47:1056-1063.

Maas LC, Harris GJ, Satlin A, English CD, Lewis RF, Renshaw PF (1997) Regional cerebral blood volume measured by dynamic susceptibility contrast MR imaging in Alzheimer's disease: a principal components analysis. J Magn Reson Imaging 7:215-219.

Maren TH (1967) Carbonic anhydrase: chemistry, physiology, and inhibition. Physiol Rev 47:595-781.

Maren TH (1977) Use of inhibitors in physiological studies of carbonic anhydrase. Am J Physiol 232:F291-F297.

Mueggler T, Baumann D, Rausch M, Rudin M (2001) Bicucullineinduced brain activation in mice detected by magnetic resonance imaging. Magn Reson Med 46:292-298.

Niwa K, Carlson GA, Iadecola C (2000a) Exogenous A $\beta 1-40$ reproduces cerebrovascular alterations resulting from amyloid precursor protein overexpression in mice. J Cereb Blood Flow Metab 20:16591668.

Niwa K, Younkin L, Ebeling C, Turner SK, Westaway D, Younkin S, 
Ashe KH, Carlson GA, Iadecola C (2000b) A $\beta 1-40$-related reduction in functional hyperemia in mouse neocortex during somatosensory activation. Proc Natl Acad Sci USA 97:9735-9740.

Phinney AL, Deller T, Stalder M, Calhoun ME, Frotscher M, Sommer B, Staufenbiel M, Jucker M (1999) Cerebral amyloid induces aberrant axonal sprouting and ectopic terminal formation in amyloid precursor protein transgenic mice. J Neurosci 19:8552-8559.

Probst A, Langui D, Ulrich J (1991) Alzheimer's disease: a description of the structural lesions. Brain Pathol 1:229-239.

Reese T, Bjelke B, Porszasz R, Baumann D, Bochelen D, Sauter A, Rudin M (2000) Regional brain activation by bicuculline visualized by functional magnetic resonance imaging. Time-resolved assessment of bicuculline-induced changes in local cerebral blood volume using an intravascular contrast agent. NMR Biomed 13:43-49.

Ridderstrale Y, Hanson M (1985) Histochemical study of the distribution of carbonic anhydrase in the cat brain. Acta Physiol Scand 124:557-564.

Rombouts SA, Barkhof F, Witter MP, Scheltens P (2000) Unbiased whole-brain analysis of gray matter loss in Alzheimer's disease. Neurosci Lett 285:231-233.

Rosen GD (2000) The mouse brain library. International Mouse Genome Conference, Narita, Japan. 14:166.

Roth LJ, Schoolar JC, Barlow CF (1959) Sulfur-35 labeled acetazolamide in cat brain. J Pharmacol Exp Ther 125:128-136.

Sandson TA, O'Connor M, Sperling RA, Edelman RR, Warach S (1996) Noninvasive perfusion MRI in Alzheimer's disease: a preliminary report. Neurology 47:1339-1342.

Severinghaus JW (1965) Handbook of physiology. III. Respiration. Baltimore: Williams and Wilkins.

Severinghaus JW (1982) Transcutaneous blood gas analysis. Resp Care 27:152-159.

Siggaard-Andersen O (1965) The acid-base status of the blood. Baltimore: Williams and Wilkins.

Sommer B, Sturchler-Pierrat C, Abramowski D, Wiederhold KH, Cal- houn M, Jucker M, Kelly P, Staufenbiel M (2000) Transgenic approaches to model Alzheimer's disease. Rev Neurosci 11:47-51.

Staufenbiel M, Sturchler-Pierrat C, Abramowski D, Duke M, Wiederhold KH, Mistl C, Rothacher S, Ledermann B, Buerki K, Frey P, Paganetti PA, Waridel C, Calhoun M, Jucker M, Probst A, Sommer B (1997) Pathological features in APP transgenic mice resembling those of Alzheimer's disease. In: Alzheimer's disease, Vol II (Friedmann E, Savage LM, eds), pp 4.2.1-4.2.12. Southborough, MA: International Business Communications IBC.

Sturchler-Pierrat C, Staufenbiel M (2000) Pathogenic mechanisms of Alzheimer's disease analyzed in the APP23 transgenic mouse model. Ann NY Acad Sci 920:134-139.

Sturchler-Pierrat C, Abramowski D, Duke M, Wiederhold KH, Mistl C, Rothacher S, Ledermann B, Burki K, Frey P, Paganetti PA, Waridel C, Calhoun ME, Jucker M, Probst A, Staufenbiel M, Sommer B (1997) Two amyloid precursor protein transgenic mouse models with Alzheimer disease-like pathology. Proc Natl Acad Sci USA 94:13287-13292.

Tago H, McGeer PL, McGeer EG (1987) Acetylcholinesterase fibers and the development of senile plaques. Brain Res 406:363-369.

Tanabe JL, Amend D, Schuff N, DiSclafani V, Ezekiel F, Norman D, Fein G, Weiner MW (1997) Tissue segmentation of the brain in Alzheimer disease. AJNR Am J Neuroradiol 18:115-123.

Thulborn KR, Martin C, Voyvodic JT (2000) Functional MR imaging using a visually guided saccade paradigm for comparing activation patterns in patients with probable Alzheimer's disease and in cognitively able elderly volunteers. AJNR Am J Neuroradiol 21:524-531.

Vorstrup S, Henriksen L, Paulson OB (1984) Effect of acetazolamide on cerebral blood flow and cerebral metabolic rate for oxygen. J Clin Invest 74:1634-1639.

Winkler DT, Bondolfi L, Herzig MC, Jann L, Calhoun ME, Wiederhold KH, Tolnay M, Staufenbiel M, Jucker M (2001) Spontaneous hemorrhagic stroke in a mouse model of cerebral amyloid angiopathy. J Neurosci 21:1619-1627. 